ELORE (ISSN 1456-3010), vol. 15 - 1/2008.

Julkaisija: Suomen Kansantietouden Tutkijain Seura ry.

[http://www.elore.fi/arkisto/1_08/saj1_08.pdf]

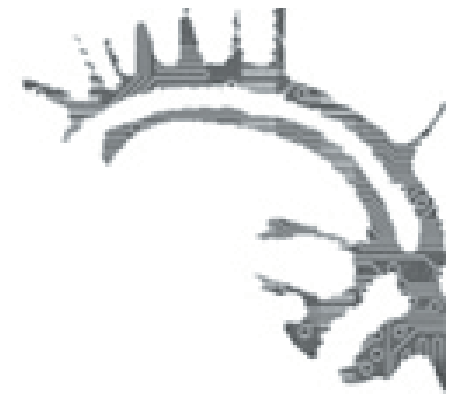

\title{
KIRJA-ARVIO:
}

\section{IRLANTILAISEN KANSANPERINTEEN KERUUN SUURTYÖ}

Briody, Mícheál 2007: Irish Folklore Commission 1935-1970: History, ideology, methodology. Studia Fennica Folkloristica 17. Helsinki: Suomalaisen Kirjallisuuden Seura. 535 sivua.

\section{$\underline{\text { Jukka Saarinen }}$}

Irish Folklore Commission (IFC), iiriksi Coimisiún Béaloideasa Éireann, oli Irlannin valtion vuosina 1935-1970 asettama ja rahoittama elin, jonka tehtävänä oli kerätä, järjestää ja julkaista irlantilaista suullista perinnettä. Mícheál Briodyn väitöskirja kertoo IFC:n työstä, valtavan irlantilaisen kansanperinteen kokoelman synnystä, ideologisesta taustasta, tavoitteista, organisoinnista, keruu- ja arkistotyön arkipäivästä - ja lopulta saavutuksista. Keskiössä on yksi henkilö, komission elinikäinen johtaja Séamus Ó Duilearga (James Hamilton Delargy), muina toimijoina poliitikkoja, virkamiehiä, irlantilaisia ja ulkomaisia tutkijoita, kerääjiä, kertojia.

Suomalainen lukija ei voi välttyä jatkuvalta vertailulta: kaksi maata, joissa kansallisen kulttuurin rakentamisella on ollut erityinen asemansa; kaksi arkistoa, joita molempia on mainittu "maailman suurimmaksi perinnearkistoksi"; kaksi rikkaaksi mainittua perinnekulttuuria. Lukiessa alkavat kuitenkin enemmän tulla esille erot, liittyivät ne sitten perinteen asemaan kansallisen kulttuurin rakentamisessa, toimintatapoihin, saavutuksiin kuin itse keruun toteutukseenkin. Kahden samanlaisen kertomuksen sijasta hahmottuu kaksi erilaista.

\section{Menestystarina}

Briodyn tutkimus on komission historia ja perustuu arkistolähteisiin. Tutkimuksen ote on mikrohistoriallinen. Komission kohtaloita seurataan välillä päivästä päivään. Komission toiminnan oma tai Ó Duileargan arkisto, jotka ovat komission seuraa- 


\section{IRLANTILAISEN KANSANPERINTEEN KERUUN SUURTYÖ}

jalaitoksen (Department of Irish Folklore, University College Dublin, nyk. UCD Delargy Centre for Irish Folklore and the National Folklore Collection) hallussa, eivät ole olleet Briodyn käytössä. Sen sijaan hän on hyödyntänyt muissa arkistoissa säilyneitä dokumentteja: virallista ja yksityistä kirjeenvaihtoa, muistioita, suunnitelmia, raportteja, budjetteja. Komissio oli Irlannin valtion asettama elin, jonka toiminnasta on paljon jälkiä viranomaisarkistoissa. Niiden avulla Briody tuo vahvasti mukaan myös rahoittajatahon näkökulman, joka "sisältäpäin" katsottuna ei olisi samalla tavalla painottunut tai tullut ymmärrettäväksi.

Briody kuvaa aluksi perinteenkeruun ja tutkimuksen kannalta olennaisen poliittisen ja kulttuuripoliittisen taustan 1900-luvun alkupuolen Irlannissa. Sieltä hahmottuu ensimmäinen ero kotoiseen tilanteeseemme: vaikka irlantilaisen suullisen perinteen rikkaus oli jo tunnettu ja kansainvälisestikin tunnustettu asia, ei suullisella perinteellä ollut samaa asemaa kansallisen historian ja sitä kautta identiteetin luomisessa. Irlannin omakielinen kirjallinen kulttuuri on vanhimpia Euroopassa, ja sen dokumenttien ja kielen tutkimuksella oli jo "kansallisen" tieteen asema. Kieli, iiri, oli keskeinen identiteettitekijä ja sen elvytys ensisijainen tavoite kansallisen kulttuurin luomisessa. Iiri oli puhekielenä vielä useassa pienessä ja kutistuvassa saarekkeessa maan länsi- ja eteläosissa. Juuri näillä alueilla vanhakantainen folklore oli elävää tai ainakin vielä saatavissa, mutta se oli nopeasti häviämässä vanhimman sukupolven ja kielen mukana. Perinteen "pelastaminen" olikin aika luonnollinen ensitehtävä komissiolle.

Otsikkonsa mukaisesti kirja kertoo komission historian, kuvailee sen työmenetelmät ja viittaa jatkuvasti ideologiaan. Historia on lyhyesti seuraava: Nuori irlantilainen keltologi Séamus Ó Duilearga kiinnostuu perinteestä ja havahtuu sen keruun tärkeyteen. Hän tutustuu Dublinissa vuonna 1927 ruotsalaiseen folkloristiin Carl Wilhelm von Sydowiin. Von Sydowin vaikutuksesta hän tekee puoli vuotta kestäneen opintomatkan erityisesti Ruotsiin, poikkeaa välillä Suomessa ja Virossakin ja tutustuu myös Kaarle Krohniin. Palattuaan Irlantiin Ó Duilearga alkaa ajaa valtiollista rahoitusta ja tukea kiireelliseksi ja tärkeäksi katsomalleen keruutoiminnalle. Vuonna 1935 valtio perustaa monien vaiheiden jälkeen perinteen keräämiseksi komission, jonka johtoon Ó Duilearga määrätään. Komissio koostuu alun perin 21 tiede- ja kulttuurialan ja valtionhallinnon edustajasta. Käytännön työstä vastaavat kuitenkin päätoimiston henkilökunta ja kerääjät. IFC aloittaa massiivisen keruun palkattujen kerääjien avulla. Vajaassa 20 vuodessa se kokoaa valtavan perinnekokoelman ja alkaa saada myös kansainvälistä tunnustusta. Väliaikaiseksi tarkoitetun komission määräaikaa jatketaan aina viideksi vuodeksi kerrallaan, kun Ó Duilearga onnistuu vakuuttamaan päättäjät siitä, että perinteenkeruu on vielä kesken. Keruutyöhön keskitytään intensiivisesti, mutta folkloristista opetusta ja tutkimusta ei oikeastaan pääse syntymään, vaikka Ó Duilearga on virallisesti UCD:n folkloristiikan lehtori ja vuodesta 1946 professorikin. 1950-luvulla henkilösuhteet IFC:n toimistossa kärjistyvät ja keruun kehitys hidastuu. 


\section{JukKa SaARInen}

\section{RISTIRIITOJA JA RANKKAA TYÖTÄ}

Briodyn pikkutarkka lähestymistapa saattaa tuntua lukijasta työläältä, mutta näin saadaan näkyviksi ne kehykset, joissa valtiorahoittaja odotti komission toimivan ja se tasapainottelu, jota Ó Duilearga harjoitti vakuuttaakseen komission toimivan odotusten mukaan mutta samalla tosiasiassa toteuttaen omaa visiotaan. IFC:n päämäärät olivat alusta alkaen kahtalaiset: kerätä ja julkaista keräämäänsä perinnettä. Kansainvälisesti merkittävän tieteelliseen perinnekokoelman luominen oli Ó Duileargan tavoite, iirin elvytyksen tukeminen perinneaineistoja julkaisemalla taas iirin kielen liikkeen ja valtion tavoite. Iirin kielen asia oli lähellä virkamieskunnan sydäntä - jopa taloudesta vastaavassa ministeriössä. Suuri osa Briodyn käyttämistä dokumenteista on alun perin kirjoitettu iiriksi, vaikka kirjassa ne on pakostakin jouduttu kääntämään englanniksi.

Toinen kiistakapula, jota Briodyn lähestymistapa hyvin valaisee, koskee komission toiminnan vakiinnuttamista. Väliaikaiseksi tarkoitettu toimintamalli venyy ja venyy, koska kokoelmien pysyvästä kodista ei päästä yksimielisyyteen. Vaikka UCD, joka oli alusta asti vahvasti toiminnassa mukana (komissio mm. toimi yliopiston osoittamissa tiloissa) olisi ollut sijoituspaikkana henkilökunnankin mielestä luonteva, se oli monille muille kelvoton vaihtoehto: takana olivat poliittiset syyt ja ennen kaikkea UCD:n haluttomuus osallistua iirin elvytykseen valtion ja iirin kielen aktivistien haluamalla tavalla. Kun "väistämätön" viimein vuonna 1970 toteutui ja kokoelmat ja henkilökunta sïrtyivät yliopiston alaisuuteen, se ei Briodyn mukaan enää taannutkaan kokoelmille parasta mahdollista kohtelua. Komission kulta-ajat saattoivat olla liian kaukana takanapäin, jotta yliopisto olisi antanut sille riittävät resurssit ja toimintaedellytykset.

Briody omistaa laajan ja kiintoisan luvun kerääjien ja heidän rankan työnsä kuvaamiselle. Ó Duilearga organisoi keruun massiiviseksi pelastustyöksi, ei Suomen mallin mukaan itse "kansaan" vetoamalla vaan palkkaamalla koko- ja osa-aikaisia kerääjiä. Kokoaikaisille maksettiin kiinteää palkkaa, osa-aikaisille tulosten mukaan. Koska ensivaiheessaan keruun tarve oli polttavin pienillä iirinkielisillä alueilla, tämä lienee ollut ainoa mahdollisuus. Pienestä paikallisväestöstä olisi tuskin löytynyt riittävästi henkilöitä, joilla olisi ollut aikaa, mahdollisuuksia, kykyä tai intoa vapaaehtoisesti uppoutua tähän työhön. Palkattujen kerääjien työtä oli myös helpompaa ohjata, valvoa ja suunnata halutuille alueille. Suomessa on totuttu sanomaan, että perinteen keruuseen on osallistunut koko kansa, vapaaehtoisesti ja pyyteettä (joskin tämä käsitys olisi päivitettävä!). Näiden kahden keruustrategian tuottamien tulosten vertailu olisikin kiintoisaa.

Tutkimusta voi lukea myös kertomuksena johtamisesta. Oli mies, jolla oli missio (pelastaa irlantilainen kansanperinne), visio (Irlannista eurooppalaisen folkloristisen tutkimuksen keskus) ja strategia (pääpanokset keruuseen). Kaikki osapuolet eivät tätä sellaisenaan jakaneet. Komissiota painostettiin julkaisemaan enemmän ja ihmeteltiin, eikö kaikki kerättävä ole jo kerätty. Maantieteellis-historiallisen metodin ihanteita toteuttava Ó Duilearga kyllä tiesi, ettei aineisto ihan kohta lopu. Johdonmukaisesti hän vei komissiota omaan päämääräänsä, priorisoi ankarasti ja piti kerääjät tiukasti henkilökohtaisessa kontrollissaan (samalla toki useimmat myös henkilökohtaisina 


\section{IRLANTILAISEN KANSANPERINTEEN KERUUN SUURTYÖ}

ystävinään). Kiintoisa yksityiskohta ovat päiväkirjat, joita kerääjiä vaadittiin pitämään aivan komission alusta alkaen. Briody omistaa kymmenisen sivua näiden päiväkirjojen alkuperän ja tarkoituksen selvittämiselle. Yksiselitteistä vastausta ei saada, koti- ja ulkomaisia esikuvia löytyy useampiakin. Päiväkirjat sisältävät kyllä kontekstitietoja, mutta yksi varteenotettava selitys, johon Briodykin viittaa, on yksinkertaisesti työn seuranta, kontrolli. Yksinään toimivien kerääjien odotettiin työskentelevän kokoaikaisesti ja päiväkirjojen avulla työnantaja olisi saattanut seurata työntekoa ja verrata sitä työn tuloksiin. Käytettiinkö niitä tähän tarkoitukseen, selviäisi (jos selviäisi) ehkä vasta itse päiväkirjoja ja Ó Duileargan omia papereita tutkimalla. Ó Duileargan johtamistapa oli tehokas ja tuotti halutun tuloksen, mutta se vaati lopulta veronsa hänen terveydessään ja ihmissuhteissaan ja lopulta myös komission toiminnassa. Vallan ja vastuun delegointi ei tähän johtamistyyliin kuulunut.

Folkloristinen tutkimus oli Ó Duileargan vision olennainen osa. Vuonna 1947 hän raportoi pääministerille: 'Nyt on tullut selväksi, että jos meille annetaan edellytykset ja voimavarat, voimme tehdä Irlannista länsieurooppalaisen tutkimuksen keskuksen suullisen perinteen ja eurooppalaisen etnologian alalla.” Näin ei kuitenkaan käynyt. Ó Duilearga ei antanut perinnetieteellistä opetusta UCD:ssa eikä sallinut alaistensakaan sitä tehdä, vaikka nämä olisivat olleet siihen halukkaitakin. Jäi muodostumatta uusi irlantilaisten folkloristien sukupolvi. Miksi? Briody antaa erilaisia vaihtoehtoja: Ó Duileargan terveys petti hänen taiteillessaan, usein turhaan, lisäresurssien saamiseksi tai komission saamiseksi pysyvälle sijalle. Hän oli koulutukseltaan keltologi eikä itse tuottanut paljoakaan folkloristista tutkimustekstiä. 1950-luvulla Ó Duileargan ja hänen lähimpien miestensä Caoimhín Ó Danachairin (Kevin Danaher) ja Seán Ó Súilleabháinin (Seán O’Sullivan) välit rikkoutuivat. Yhä edelleenkin Ó Duilearga suuntasi voimavarat keruuseen. IFC oli alkanut saada kansainvälistä tunnustusta työstään ja kokoelmistaan maineikkailta folkloristeilta (mm. Stith Thompson). Väistämättä ainakin minulle tulee mieleen, että ehkä Ó Duileargan visio ei niinkään ollut luoda irlantilaista folkloristiikkaa kuin tarjota näitä upeita ja kiitettyjä, jatkuvasti kartutettavia aineistoja kansainväliselle tutkimukselle. On paradoksaalista, että kun IFC vuonna 1970 sulautettiin osaksi samaan aikaan perustettua UCD:n folkloristiikan laitosta, ne perinteentutkimuksen ideologiat ja tutkimussuunnat, jotka kokoelman alulle saattoivat, olivat kansainvälisesti jo jääneet uuden folklorististen ajattelun alle.

\section{KERUU JA SEN YMMÄRTÄMINEN}

Mícheál Briodyn väitöskirja ei ole irlantilaisen kansanperinteen analyysi eikä opas arkiston kokoelmiin, mutta se auttaa käyttäjää ymmärtämään kokoelmia paremmin. Tutkimuksen pääpaino on koko ajan keruussa ja kysymyksissä miksi ja miten, ei mitä. Se ei myöskään ole folkloristisen tutkimuksen oppihistoria. Keruu asetetaan aikansa vallitsevan folkloristisen tutkimussuunnan, vertailevan maantieteellis-historiallisen tutkimuksen ja pohjoismaisten esikuvien kontekstiin. Enempää on vaikea sanoakaan, koska toiminta oli melkoisen immuunia uusille kansainvälisille tutkimuksellisille 


\section{JukKa SaARInen}

vaikutteille. Työskentelytavoissaan komissio toki oli sekä innovatiivinen että seurasi aikaansa. Jo varhain Ó Duilearga tajusi äänitystekniikan arvon. Perinnetekstien keruussa hyödynnettiin edifonia (fonografia) alusta pitäen. Musiikin ja perinnenäytteiden äänitykseen hankittiin levytyslaitteet. Vuosina 1937-1938 organisoitiin melkein koko maan kattava perinnekeruu koulujen kautta ('The Schools Scheme"), jolla saatiin arvokasta tietoa perinteestä niiltä alueilta, joihin palkattu keruu ei ollut ulottunut.

Briody arvioi loppuluvussa komission työtä ja sen tuloksia nostaen muutamia seikkoja tarkempaan käsittelyyn. Näitä ovat muun muassa edellä mainitut kerääjien päiväkirjat ja keruun olemattomuus kaupungeissa. Jälkimmäinen ei ajan folkloristisessa ilmapiirissä ole kovin kummallista, ei "kansa" suomalaisessakaan keruussa siirtynyt kaupunkiin ennen 1960-luvun loppua. Hätkähdyttävin ajatus on kuitenkin kysymys, estikö komissio, tai jätti ainakin rohkaisematta, kerääjiensä kehittymistä folkloristeina. Kun itse on sisäistänyt (paikallis)kerääjä-tutkija-dikotomian, ajatus tuntuu lennokkaalta. Komission kokopäiväiset kerääjät, jotkut heistä vuosikymmeniä sen palveluksessa olleita, kehittyivät varmasti ajan myötä oman toiminta-alueensa perinteen eksperteiksi. Jotkut heistä julkaisivat myöhemmin kirjoja kokemuksistaan, tapaamistaan ihmisistä ja perinteestä. Minkälaista folkloristiikkaa kerääjä-tutkijat olisivat tehneet, jää pohtimatta. Olisiko heidän tietämyksensä perusteella ja heitä kouluttamalla kenties ollut mahdollista synnyttää erilainen irlantilainen folkloristiikka, vähemmän vertaileva ja enemmän ymmärrystä lisäävä? Ehkä, mutta kovasti se olisi ollut aikaansa edellä, eikä kansainvälinen tiedeyhteisö sitä tuolloin olisi tunnustanut.

IFC:n saavutuksia arvioitaessa arvioidaan väistämättä myös Séamus Ó Duileargan elämäntyötä. Perinnekokoelmat eivät sukeudu ja kehity itsestään. Ne vaativat ihmisiä, ne vaativat tahtoa. Briody kirjoittaa Ó Duileargasta avoimesti ja vaikeita asioita kaihtamatta, kriittisestikin, mutta samalla ymmärtäen ja kunnioittavasti. Keruuhistoria on kokoelmien ymmärtämiselle välttämätöntä, eivätkä pelkästään itse keruutyön vaiheet vaan myös sen organisatoriset, taloudelliset ja ideologiset taustat. Mícheál Briodyn 500-sivuinen väitöskirja täyttää upeasti tätä tiedon aukkoa irlantilaisen perinnekokoelman osalta. Toivoa sopii, että sama tehtäisiin täällä meilläkin.

Jukka Saarinen on Suomalaisen Kirjallisuuden Seuran kansanrunousarkiston erikoistutkija, joka on opiskellut stipendiaattina UCD:n Department of Irish Folkloressa vuosina 1984-1985. 